ARGONNE NATIONAL LABORATORY

\title{
Study of a Dry Room in a Battery Manufacturing Plant using a Process Model
}

\section{Shabbir Ahmed (Corresponding Author)}

Chemical Sciences and Engineering Division, Argonne National Laboratory, Bldg. 200, 9700 S. Cass Avenue, Argonne IL 60439 USA

ahmeds@anl.gov, Tel: (630) 252-4553, Fax: (630) 972-4553

\section{Paul A. Nelson}

Chemical Sciences and Engineering Division, Argonne National Laboratory, Bldg. 200, 9700 S. Cass Avenue, Argonne IL 60439 USA

nelsonp@anl.gov

Dennis W. Dees

Chemical Sciences and Engineering Division, Argonne National Laboratory, Bldg. 200, 9700 S. Cass Avenue, Argonne IL 60439 USA

dees@anl.gov 


\begin{abstract}
The manufacture of lithium ion batteries requires some processing steps to be carried out in a dry room, where the moisture content should remain below 100 parts per million. The design and operation of such a dry room adds to the cost of the battery. This paper studies the humidity management of the air to and from the dry room to understand the impact of design and operating parameters on the energy demand and the cost contribution towards the battery manufacturing cost. The study is conducted with the help of a process model for a dry room with a volume of 16000 cubic meters. For a defined base case scenario it is found that the dry room operation has an energy demand of approximately $400 \mathrm{~kW}$. The paper explores some tradeoffs in design and operating parameters by looking at the humidity reduction by quenching the make-up air vs. at the desiccant wheel, and the impact of the heat recovery from the desiccant regeneration cycle.
\end{abstract}

\title{
Keywords
}

Dry room, lithium ion battery, battery manufacturing, humidity control 


\section{Table of Contents}

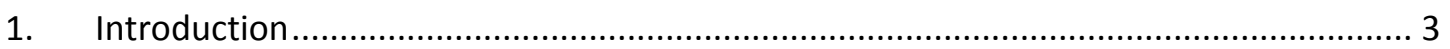

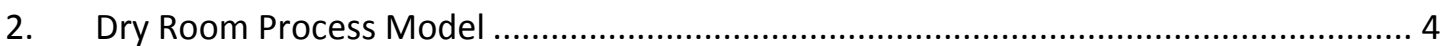

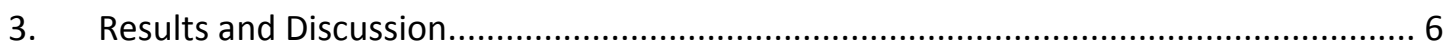

3.1. Moisture Entering the System and Its Removal ..................................................... 9

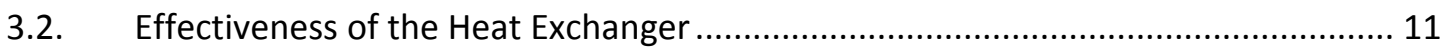

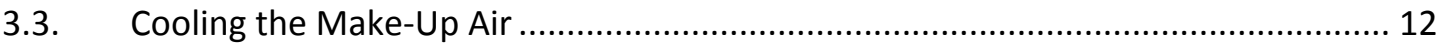

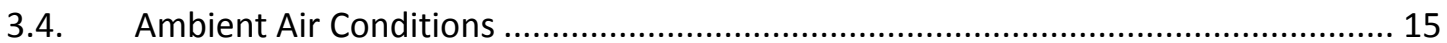

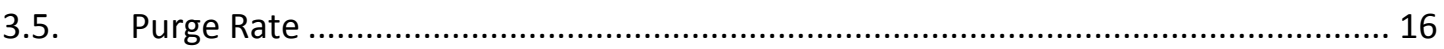

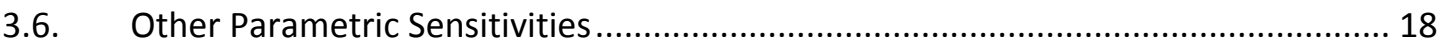

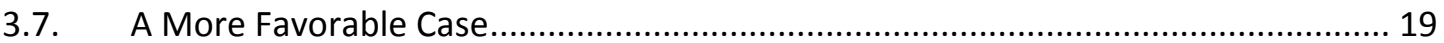

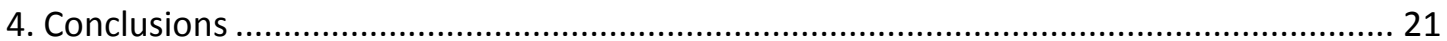

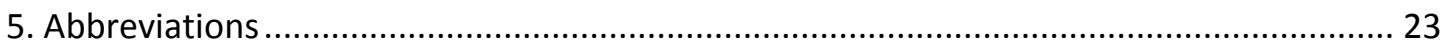

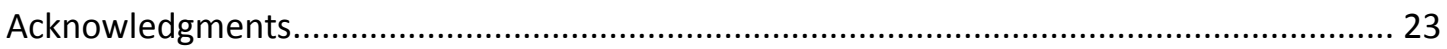

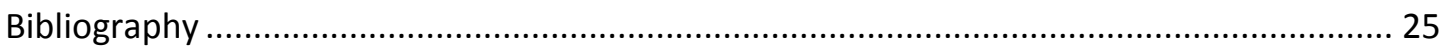




\section{Introduction}

Increasing demand for lithium ion batteries (LIB) [1] and the resultant demand for reliable dry rooms [2] have spurred numerous suppliers offering dry room technologies. The trend is toward larger manufacturing plants to benefit from economies of scale [3]. These plants seek to squeeze out inefficiencies and cost factors. The dry room represents a step in the manufacturing process where the energy demand is very high because of the large volume of air that needs to be temperature controlled and dried.

A dry room is an essential part of the manufacturing plant for lithium ion batteries [4] [5] [6]. Here the cells are filled with the electrolyte which is very sensitive to moisture (e.g., lithium hexafluoride reacts with water) and sealed in an environment with moisture concentrations below 100 parts per million by volume (ppmv). Small variations in the moisture content can affect the capacity and/or the cycle life of the cells produced [7].

The dry room environment is maintained by designing a leak-proof contained volume, where the incoming air contains very low moisture content (say $15 \mathrm{ppm}$ or 0.066 grains per pound (gpp)), such that the exit gas does not exceed the specified upper limit (say 100 parts per million volume (ppmv) or $0.44 \mathrm{gpp}$ ). The air flow rate through the dry room is controlled with sensors to maintain the exit gas at a moisture content of $100 \mathrm{ppm}$ or less. Management of ventilation through a combination of vent placement and air flows ensures rapid resolution of any occasional spikes in moisture at key spots in the room [8]. The room enclosure is kept leak-proof which includes use of a 
vapor barrier seal on the concrete floor followed by an epoxy finish coat. Some key parameters in the design of the dry room include the volume of the room, the allowable moisture concentration, and the amount of moisture released from the materials entering and personnel working in the room [9].

The objective of this paper is to estimate the energy consumption and the cost contribution to the battery manufacturing plant from operating a dry room. A generic system diagram has been proposed to enable a reasonable estimate of the cost and energy demand of operating a dry room.

\section{Dry Room Process Model}

This study was conducted for a dry room in a battery manufacturing plant that will produce 100,000 packs of automotive lithium ion batteries (LIB). The plant equipment is amortized over 6 years. The dry room is assumed to have a volume of $16,000 \mathrm{~m}^{3}$. 


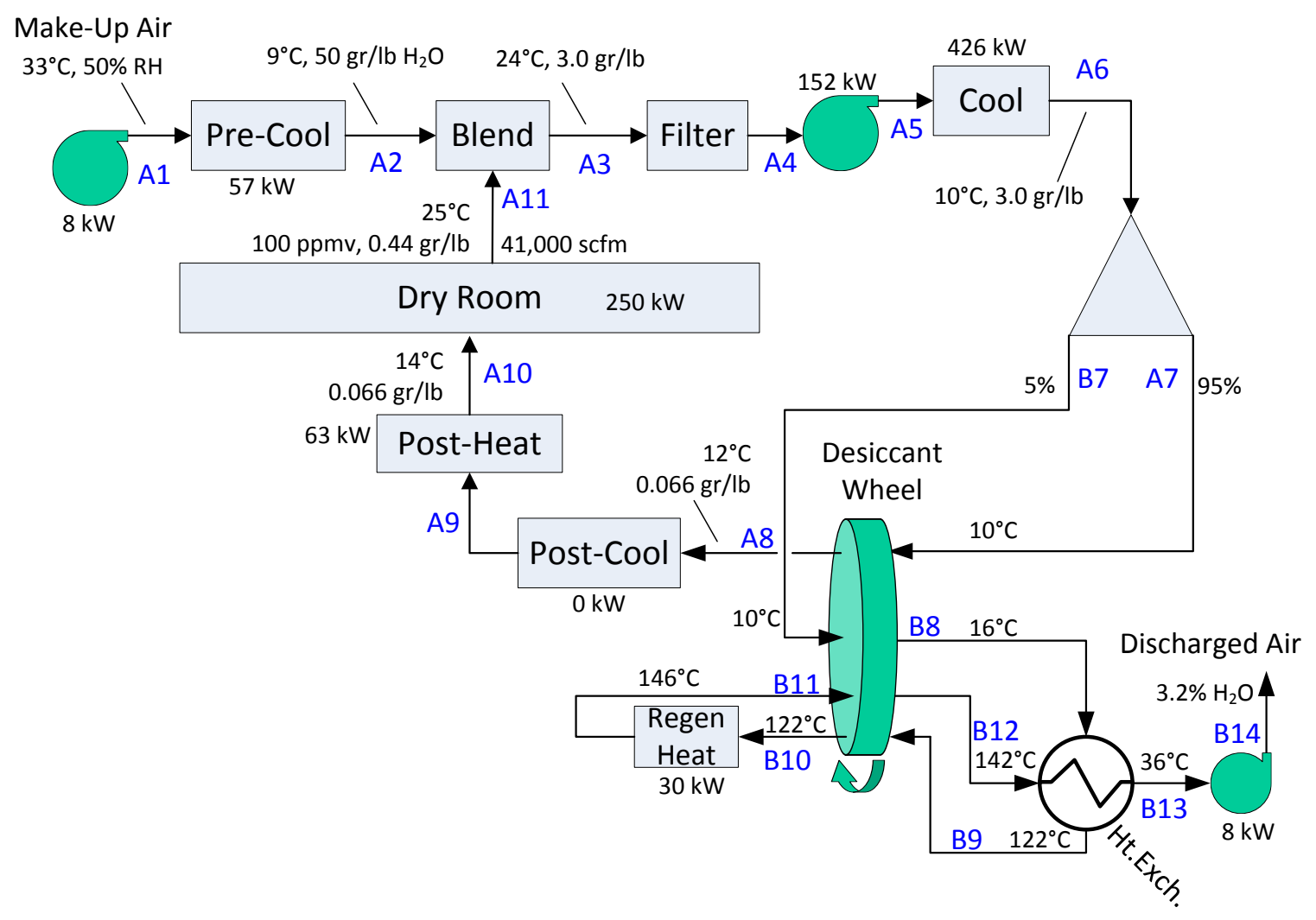

Figure 1. Schematic of the air management for the Dry Room

Figure 1 is a schematic of the management of the air supply for the dry room, including some assumptions, input parameters, and calculated results for a base case system. The make-up air at $33^{\circ} \mathrm{C}, 50 \%$ relative humidity $(\mathrm{RH})$ or 2.5 vol.\% moisture, is pre-cooled to $9^{\circ} \mathrm{C}$ to drop out some of the moisture and then blended with the return air from the dry room. The combined stream emerges at a temperature of $24^{\circ} \mathrm{C}$ and a moisture content of 0.07 vol.\% (3 gpp). This stream is filtered and cooled down to $10^{\circ} \mathrm{C}$, and then split with 95\% going towards the dry room (A7-A10), the balance (purge stream) to be eventually discharged (B7-B14) from the system. A low purge rate $(5 \%)$ is advantageous in that it lowers the heating and cooling loads in the system, and is 
discussed in Section 3.5. The dry-room stream is passed through a desiccant wheel where the moisture content is reduced to $15 \mathrm{ppmv}(0.066 \mathrm{gpp})$. This gas is then heated or cooled as needed such that the dry room exit air is at $25^{\circ} \mathrm{C}$. For this base case scenario, the dry room inlet temperature is $14^{\circ} \mathrm{C}$. Within the dry room the air picks up moisture from the personnel, from the negative electrodes that come in with moisture content, and the opening of the airlock doors. The air flow rate and its inlet temperature are calculated such that the return air is at $25^{\circ} \mathrm{C}$ and with a moisture content of 100 ppmv (0.44 gpp), or less. For the base case set of conditions, the inlet air is at $14^{\circ} \mathrm{C}$ and the air flow rate is $20 \mathrm{~m}^{3} \mathrm{~s}^{-1}\left(41,000 \mathrm{ft}^{3} \mathrm{~min}^{-1}\right)$. This air flow rate corresponds to a residence time of 13.6 minutes within the dry room.

The desiccant wheel is regenerated by passing the discharge air stream heated to $146^{\circ} \mathrm{C}$. The discharge air stream flows multiple times through the desiccant wheel to heat and cool the desiccant wheel and to allow for recovery of some of the sensible heat, as shown in the figure. Table 1 lists the assumptions and input parameters used in calculating the results shown in Figure 1.

Table 1. Assumed / Input Parameters in Dry Room Process Model (Base Case)

\section{Results and Discussion}

With the dry room inlet and exit air streams stipulated to contain 15 ppm (0.066 gpp) and 100 ppm (0.44 gpp) of moisture, respectively, the air flow needed through the 
dry room is calculated to be $19.6 \mathrm{~m}^{3} \mathrm{~s}^{-1}\left(41,600 \mathrm{ft}^{3} \mathrm{~min}^{-1}\right)$. This flow represents a residence time or volumetric air turnover every 13.6 minutes. With the heat generated in the dry room assumed to be $250 \mathrm{~kW}$, the inlet air temperature needs to be at $14^{\circ} \mathrm{C}$ to ensure that the air leaving the dry room is at the specified $25^{\circ} \mathrm{C}$.

Table 2. Moisture Content and Energy Demands in the Process (Base Case)

Table 2 shows the heating and cooling loads for the steps in the process. The largest cooling load of $426 \mathrm{~kW}$ is at the Cool station (A5-A6). The combined cooling load at three stations (Pre-Cool, Cool, and Post-Cool) is $483 \mathrm{~kW}$. Assuming a coefficient of performance of 3.5 , the electric power needed for the heat removal is $138 \mathrm{~kW}$. A heating load of $30 \mathrm{~kW}$ is needed to regenerate the desiccant wheel. Electric power is needed for the blowers (167 kW) and refrigeration (138 kW), adding up to $305 \mathrm{~kW}$. The thermal energy requirements are at Post-Heat $(63 \mathrm{~kW})$ and for the discharge air heating for zeolite wheel regeneration $(30 \mathrm{~kW})$. The total energy requirement for the operation (the sum of the thermal and electrical) is $398 \mathrm{~kW}$. If we consider that the electric power from the grid is generated from natural gas (NG) with an efficiency of $40 \%$, then the energy required for the system becomes $((138+167) / 0.4+93=) 856 \mathrm{~kW}$. Using the EPA greenhouse gas equivalencies calculator [10], the greenhouse gas emissions from the generation of the thermal and energy usage for the dry room air management converts to $5.4 \mathrm{MT}$ of $\mathrm{CO}_{2}$ Equivalent. These estimates do not include the inefficiencies of heat transfer in the dry room system. 
The modeling results were used to estimate the cost of the capital equipment and raw materials, while the labor requirement for the baseline plant was estimated from private communications with knowledgeable individuals. These are shown in Table 3.

Table 3. Costs for the Base Case System

The cost of the dry room operations was based on an algorithm defined by Peters and Timmerhaus [11], which also provides a range of percentages. Table 4 lists the estimated percentages for the cost assessment in column 2. The annual cost of operations was then calculated by adding the Total Operating Cost to the annualized total capital investment.

The cost of the dry room operations was estimated to be $\$ 3.5 \mathrm{M}$ per year, or $\$ 35$ per pack, or $\$ 1270$ per $\mathrm{m}^{3}$ of the dry room, for the plant producing 100,000 battery packs per year. For reference, Argonne's BatPaC model [12] [13] estimates the cost of a 10 kWh battery for a Plug-in Hybrid Electric Vehicle (PHEV) producing 100K packs per year is $\$ 3100$ per pack.

Table 4. Assumed Input Parameters in Cost Estimate

To gain perspective on the effect of inaccuracies in the assumed values in preparing the estimate, an alternative estimate was obtained by using a range of the percentages for the parameters in Table 4, which are shown in column 4. A random 
number generator was used to generate a percentage value within the range for each cost item to calculate the cost of dry room operations. This was repeated over 1000 times, to yield an average value of $\$ 38$ per pack, with a standard deviation of $\$ 2$. The results were spread between a maximum and minimum of $\$ 46$ and $\$ 31$, respectively, with a frequency distribution as shown in Figure 2.

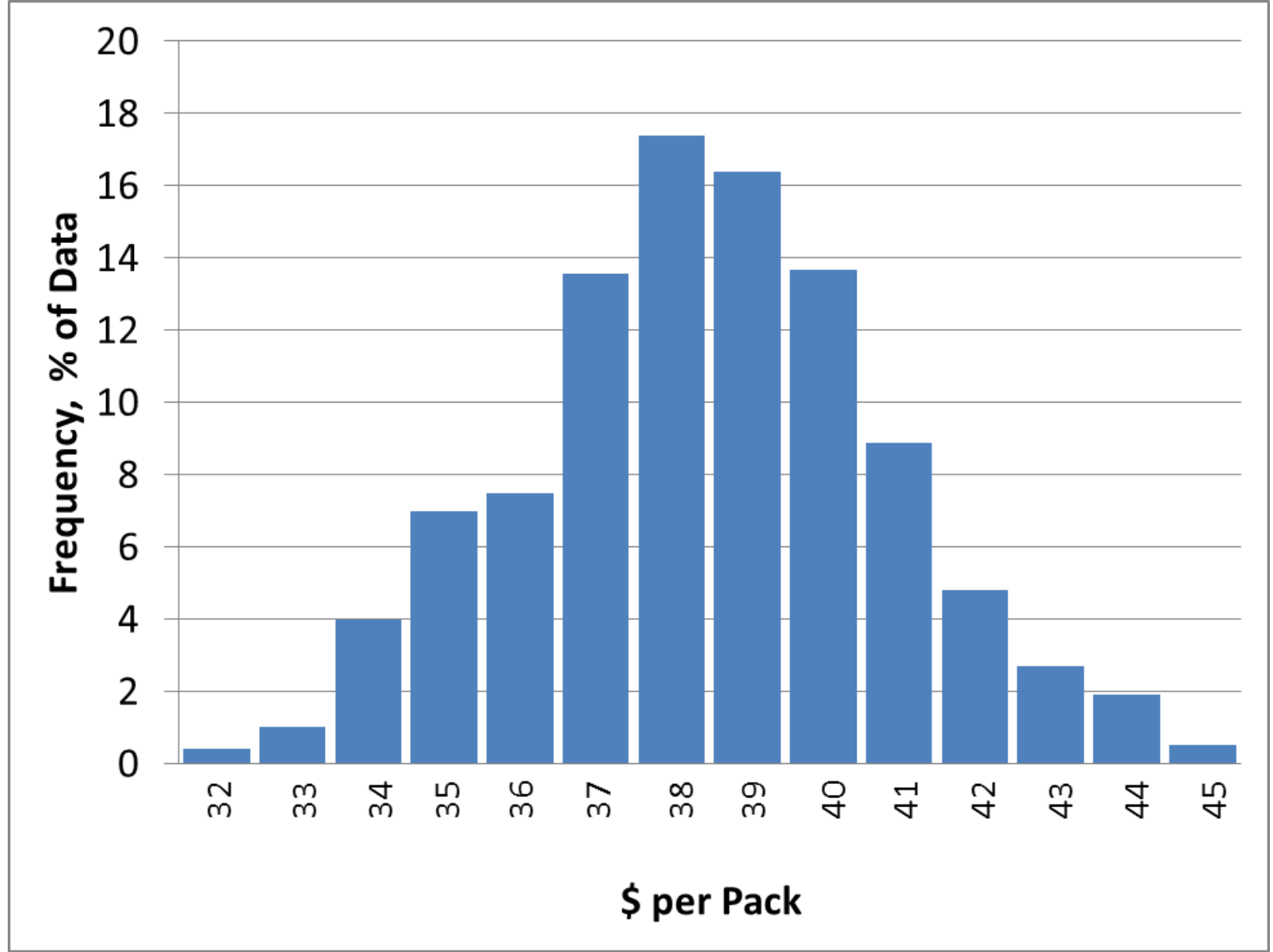

Figure 2. Frequency distribution of cost calculations using randomized percentages from Table 4, column 4.

\subsection{Moisture Entering the System and Its Removal}


The moisture mainly comes into the system with the make-up air. At $33^{\circ} \mathrm{C}$ and $50 \% \mathrm{RH}$, water vapor enters the system at a rate of $19.4 \mathrm{~g} \mathrm{~s}^{-1}\left(1.08 \mathrm{~mol} \mathrm{~s}^{-1}, 2.5\right.$ vol.\%). The Pre-Cool station cools the gas to $9^{\circ} \mathrm{C}$ and condenses out $10.6 \mathrm{~g} \mathrm{~s}^{-1}$ of moisture. The second source of moisture into the system is with the materials and personnel entering the dry room, adding $1.23 \mathrm{~g} \mathrm{~s}^{-1}$. Blending the make-up air with the return air from the dry room (containing 100 ppmv $\mathrm{H}_{2} \mathrm{O}$ or $0.066 \mathrm{gpp}$ ), results in the mixture with a moisture content of $682 \mathrm{ppm}$ ( $3 \mathrm{gpp})$. The Cool station reduces the mixture temperature to $10^{\circ} \mathrm{C}$ (saturated vapor pressure is $1.2 \mathrm{vol} . \%$ ) but because of the already low moisture content, no further condensation occurs at this station. The main air stream (A7) undergoes the final moisture removal at the desiccant wheel, where $9.5 \mathrm{~g} \mathrm{~s}^{-1}(0.53$ $\left.\mathrm{mol} \mathrm{s}^{-1}\right) \mathrm{H}_{2} \mathrm{O}$ is adsorbed, dropping the moisture level in the air to 15 ppmv (0.066 gpp).

The air emerging from the desiccant wheel is warmed up to $\sim 12^{\circ} \mathrm{C}$ because of the heat of adsorption that is generated when the moisture is adsorbed onto the desiccant. This air stream is then heated to $14^{\circ} \mathrm{C}$ before entering the dry room.

Within the dry room, moisture is released by the personnel and negative electrodes, while some moisture enters during the opening of the air lock doors. This breakdown is shown in Table 5.

Table 5. Moisture Source in Dry Room 
The discharge stream from the splitter carries $0.51 \mathrm{~g} \mathrm{~s}^{-1}\left(0.028 \mathrm{mols} \mathrm{s}^{-1}\right)$ of moisture and extracts the $9.5 \mathrm{~g} \mathrm{~s}^{-1}$ of moisture that was adsorbed on the desiccant wheel. The discharge stream exits the system at $\sim 36^{\circ} \mathrm{C}$ with $10.0 \mathrm{~g} \mathrm{~s}^{-1}$ of moisture (1.3 vol.\%). The saturated vapor pressure at $36^{\circ} \mathrm{C}$ is approximately $6 \%$. The material balance for the moisture entering and leaving the system is shown in Table 6.

Table 6. Moisture Entering and Leaving the System

\subsection{Effectiveness of the Heat Exchanger}

Figure 1 shows a heat exchanger being used to recover part of the energy needed to regenerate the desiccant wheel. With an approach temperature of $20^{\circ} \mathrm{C}$, the heat exchanger requires a heat transfer area of $2200 \mathrm{~m}^{2}$. Eliminating the heat exchanger would simplify the process but it would increase the heat load on the air heater by a factor of more than 5, from 30 to $168 \mathrm{~kW}$. The feasibility of a smaller heat exchanger was explored by studying the effect of the approach temperature by varying it from $20^{\circ} \mathrm{C}$ to $132^{\circ} \mathrm{C}$ (no heat exchanger needed). Figure 3 shows that with increasing approach temperature, the heat load needed to raise the discharge air temperature to $146^{\circ} \mathrm{C}$ (for desiccant regeneration) increases linearly. The larger approach temperature allows for a smaller heat exchanger, as shown by the non-linear decrease in the heat transfer area requirement. The cost of the dry room operations (\$ per pack) decreases, and is lowest without the heat exchanger. 


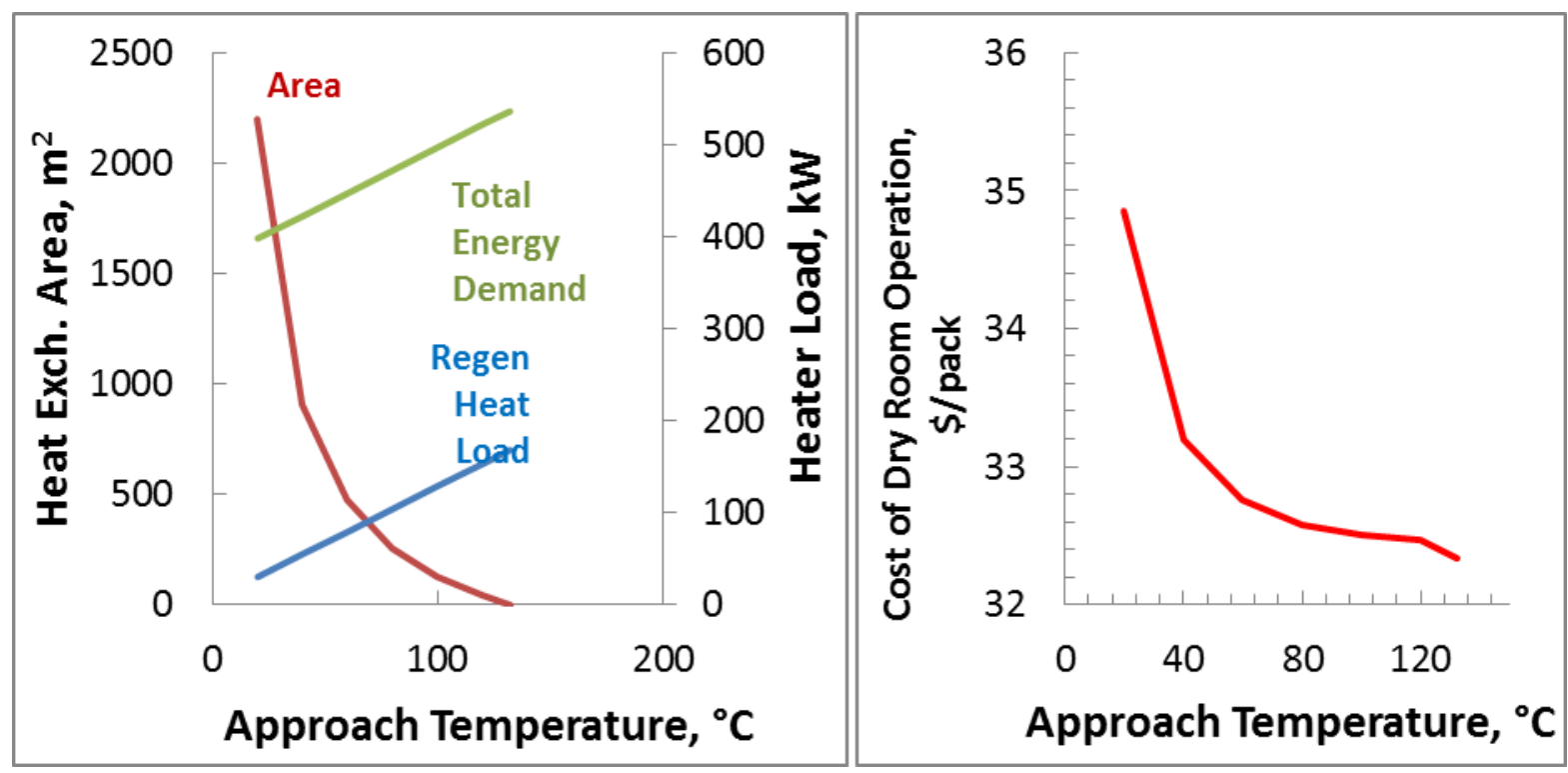

Figure 3. The heat exchanger size and cost of natural gas determines the cost of the dry room operations. Natural gas $=2$ cents $\mathrm{kWh}^{-1}$.

\subsection{Cooling the Make-Up Air}

The Pre-Cool station cools the incoming make-up air to condense out a significant portion of the moisture in the make-up air. For the base case scenario, the heat removal load for cooling to $9^{\circ} \mathrm{C}$ in this step is $57 \mathrm{~kW}$. The extent of cooling at this station has ramifications at points downstream. A look at the effect of the temperature setting at the Pre-Cool station was conducted by varying the temperature from $1^{\circ}$ to $33^{\circ} \mathrm{C}$. The effect is shown in Figure 4 and Table 7.

Lowering the Pre-Cool temperature from $33^{\circ} \mathrm{C}$ (no precooling) changes the cooling load at the Pre-Cool station from zero to $76 \mathrm{~kW}$ at $1^{\circ} \mathrm{C}$, and at the Cool station from 457 to $416 \mathrm{~kW}$. The combined cooling load increases by $8 \%$, from $457 \mathrm{~kW}$ at $33^{\circ} \mathrm{C}$ to $492 \mathrm{~kW}$ at $1^{\circ} \mathrm{C}$. 
As the Pre-Cool setting is lowered, the amount of heat needed at the Post-Heat increases from 20 to $78 \mathrm{~kW}$. The total thermal energy load increases by 96\% (54 to 106 $\mathrm{kW}$ ) when the Pre-Cool temperature is reduced from $33^{\circ} \mathrm{C}$ to $1^{\circ} \mathrm{C}$. The Total Energy Need represents the sum of the thermal energy load and the power needed for refrigeration (=Cooling Load / Coefficient of Performance). The Total Energy Need increases $18 \%$, from 351 to $414 \mathrm{~kW}$ as the Pre-Cool setting is reduced from 33 to $1^{\circ} \mathrm{C}$. There appears to be a small increase in the cost of operations as the Pre-Cool temperature is lowered. However, the lower Pre-Cool temperature settings reduces the burden of removing moisture at the zeolite wheel, which can then turn slower and also benefit from a smaller temperature differential as a result of the heat effects of less adsorption and desorption.

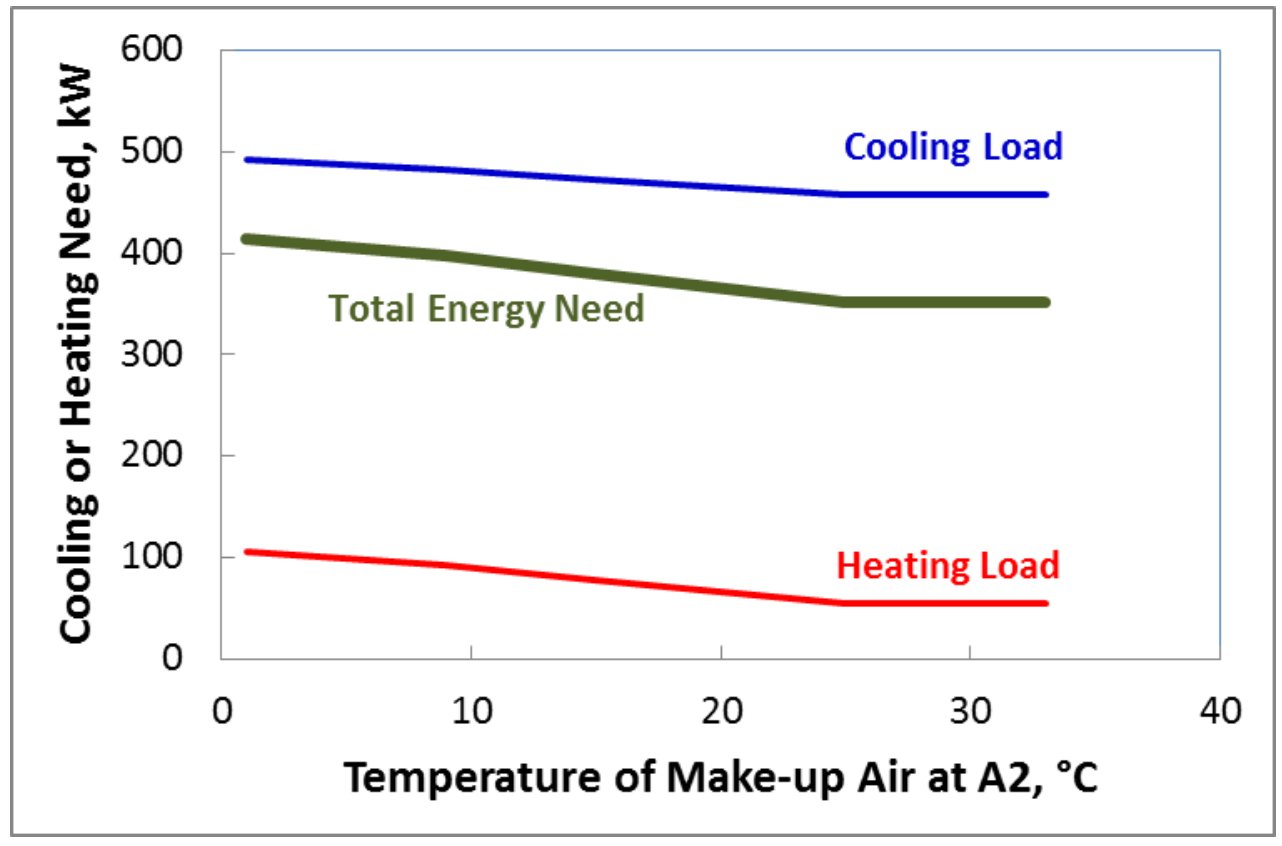

Figure 4. Effect of the Pre-Cool Temperature Setting on the Heating and Cooling Needs 
Table 7. Effect of the Pre-Cool Temperature on Heating and Cooling

The distribution of water removal from the system as a function of the Pre-Cool temperature is shown in Table 8 . At $9^{\circ} \mathrm{C}, 55 \%$ of the water entering with the make-up air (51.5\% of the total water entering the system) is removed at the Pre-Cool station. The balance is removed with the purge stream (2.5\%) and via the desiccant wheel (46.0\%), ultimately leaving with the discharge stream (B14). With a setting of $33^{\circ} \mathrm{C}$, there is no water removal at the Pre-Cool station. Thus all the water is removed via the desiccant wheel (94.9\%) and the purge stream (5.1\%). The trends of the water distribution at the different temperatures are shown in Figure 5.

Table 8. Mass balance for water at two Pre-Cool temperature settings.

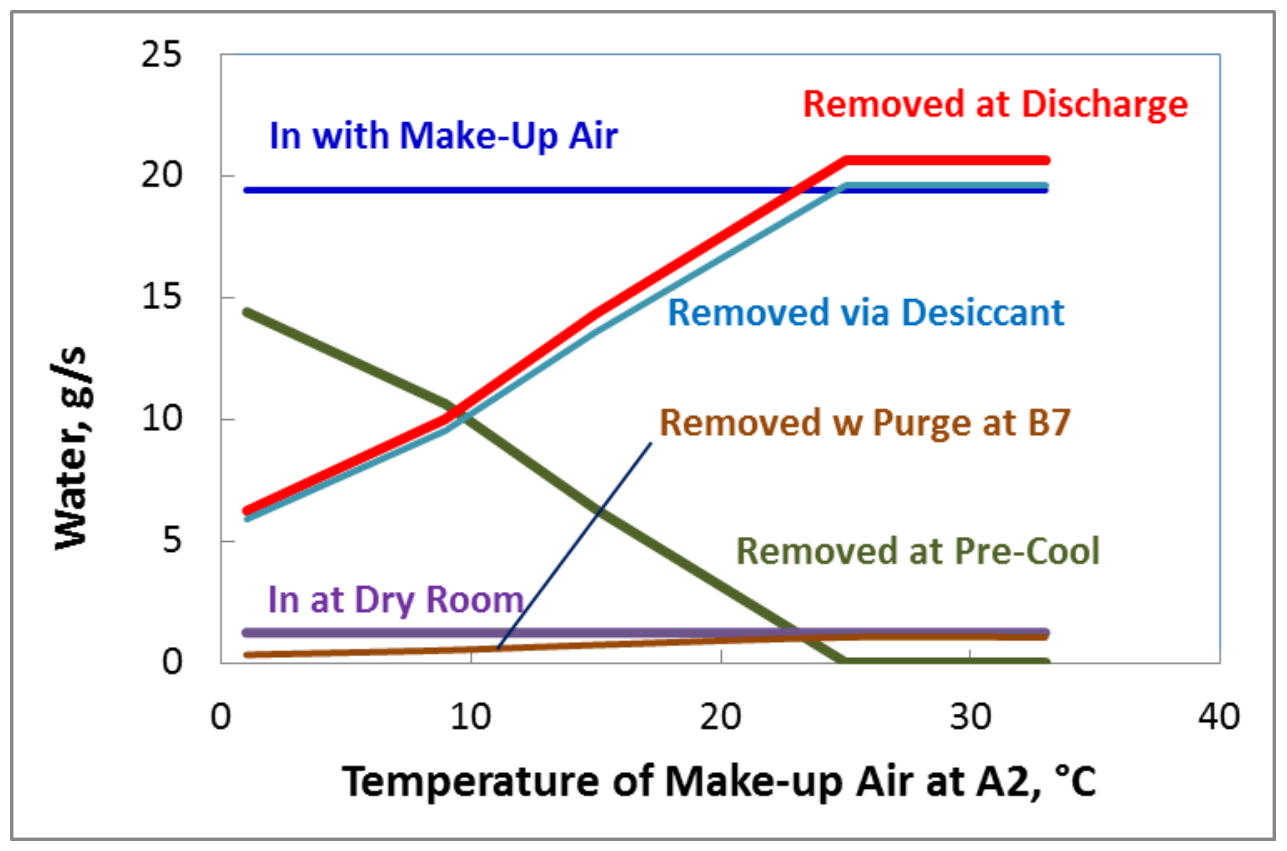

Figure 5. Distribution of Water into and out of the process as a function of the Pre-Cool temperature. 


\subsection{Ambient Air Conditions}

The main function of the operations supporting the dry room is to ensure that the moisture content brought in with the ambient make-up air and the moisture that is introduced / generated within the dry room is reduced to very low levels. For the Base Case conditions, the moisture coming in with the make-up air is overwhelmingly higher (by 2 orders of magnitude) than from inside the dry room. Furthermore, the temperature of the ambient air also varies with the plant location and season.

The effect of the ambient air conditions was studied by varying the temperature from $40^{\circ} \mathrm{C}$ to $-17.8^{\circ} \mathrm{C}\left(104^{\circ} \mathrm{F}\right.$ to $\left.0^{\circ} \mathrm{F}\right)$. The $\mathrm{RH}$ was held constant at $50 \%$ for all temperatures. With lower temperatures and lower moisture content, the cooling load at the Pre-Cool station diminishes and becomes zero at $9^{\circ} \mathrm{C}$ (the Pre-Cool set temperature). At temperatures below $9^{\circ} \mathrm{C}$, the load at the Cool station is also reduced. The drier air entering the desiccant wheel generates less heat of adsorption and so the gas exits (A8) at a lower temperature. The effect of the ambient air temperature on the heating and cooling demands, as well as the overall energy demand for the dry room operation are shown in Figure 6 and Table 9. Over the range of temperature studied, the Total Energy Need is found to pass through a minimum value of $385 \mathrm{~kW}$ when the ambient air is at $20^{\circ} \mathrm{C}$; at still lower temperatures more energy is needed at Post-Heat to meet the dry room inlet temperature requirement.

The effect on cost is also shown in Figure 6, where the cost of electricity decreases, while the cost of natural gas increases with decreasing ambient temperatures. The total 
cost of operations ( $\$$ per pack) is seen to decrease sharply from $40^{\circ} \mathrm{C}$ to $20^{\circ} \mathrm{C}$, and then more gradually, reflecting the slopes of the other energy and cost curves.

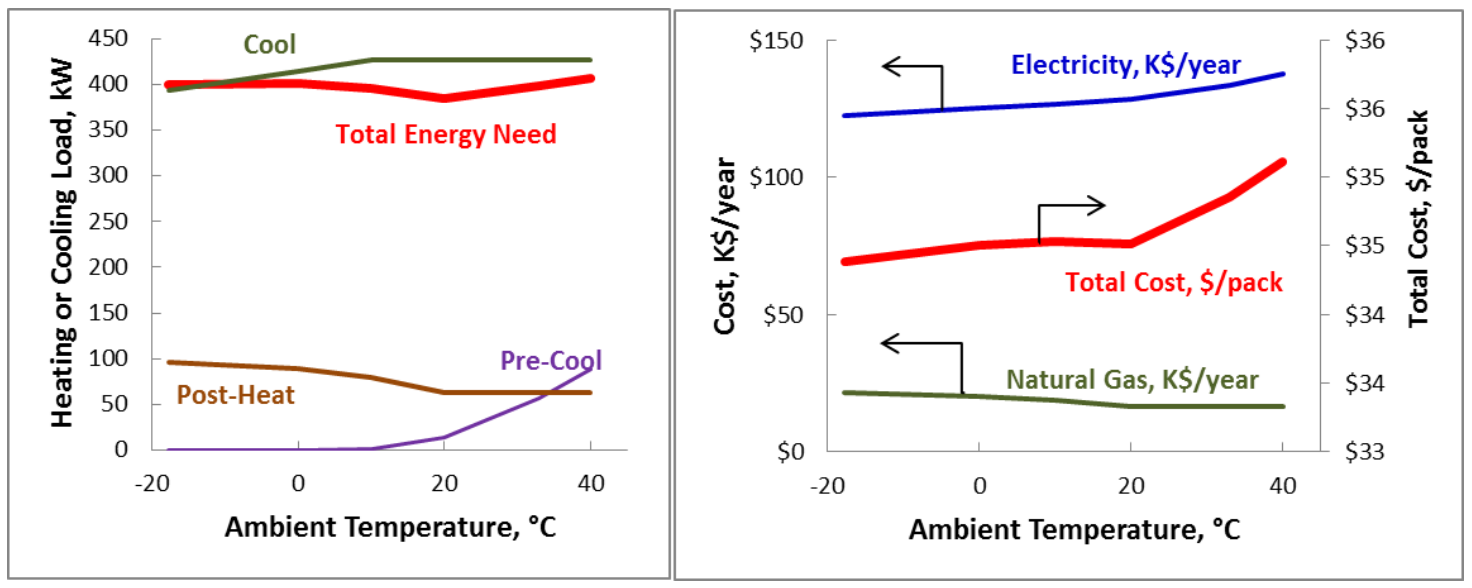

Figure 6. Effect of the Ambient Air Temperature on the Energy Demands and Costs ( $\mathrm{RH}=50 \%)$.

Table 9. Effect of Ambient Air Temperature Heating and Cooling Needs, and Costs ( $\mathrm{RH}=50 \%)$.

\subsection{Purge Rate}

Purging is necessary in a recirculating system to limit the buildup of some species. In the case of the dry room, moisture and carbon dioxide are generated. Both these species are removed effectively by the molecular sieve used in the desiccant wheel, as these molecular sieves are also used for drying and $\mathrm{CO}_{2}$ removal from natural gas [14]. The purge flow ensures that the concentrations of any other chemical species that are not removed via condensation or the molecular sieve do not build up too much.

The purge rate determines the amount of make-up air needed and, therefore, is a significant determinant in the energy needs and the cost of operations. The effect of the 
purge rate was studied by varying it from the base case of $5 \%$ to $20 \%$. A higher flow associated with increasing the purge / make-up air increases the heat removal loads. The larger moisture content entering the system increases the heat effects of the zeolite wheel, and the heat required for regeneration. Thus, increasing the purge rate increases the energy demand (cooling and heating) and equipment sizes, all of which lead to higher costs of operation. Raising the purge rate from the base case of $5 \%$ to $20 \%$ purge, increases the energy demand by $62 \%$ to $645 \mathrm{~kW}$ and increases the cost per pack for the dry room operations by $10 \%$ to $\$ 38.37$. These results are summarized in Figure 7 and Table 10.

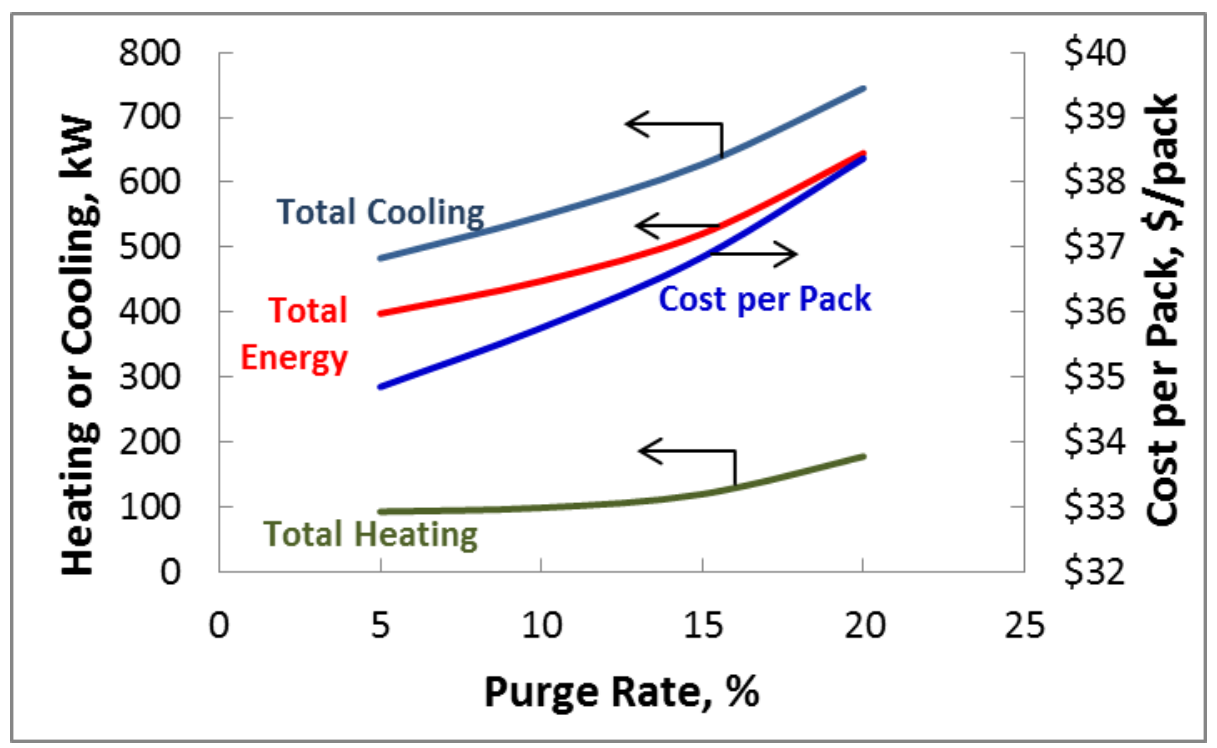

Figure 7. Effect of the purge rate on the heating and cooling needs, and the cost of operations.

Table 10. The heating and cooling needs, and the cost of operating the dry room at different purge rates. 


\subsection{Other Parametric Sensitivities}

The model includes a large number of assumed input values and the sensitivity of the output values to some of these parameters has been studied. The effects of plant life, the volume of the dry room, the prices of natural gas and electricity, and the coefficient of performance are shown in Figure 8. Changing the amortization rate from the base case of 6 years to 4 or 8 years changes the cost of the dry room operation from $\$ 34.85$ per pack to $\$ 43.45$ or $\$ 30.55$, respectively. Changing the size of the dry room by $10 \%$ changes the per pack cost by a dollar or approximately $3 \%$. Changing the price of electricity from the base case 0.5 cents per kWh to 0.3 or 0.7 , changes the cost from $\$ 34.85$ to $\$ 34.11$ or $\$ 35.59$, respectively. A $40 \%(100 \mathrm{~kW})$ change in the amount of heat generated in the dry room changes the temperature setting of the dry room inlet air and therefore the heat load, thereby changing the cost by 60 cents per pack. Changing the COP from 3.5 to 3 or 4 , changes the cost by approximately 10 cents per pack, while a 1 cent per kWh change in the price of natural gas changes the operations cost by about 11 cents per pack. 


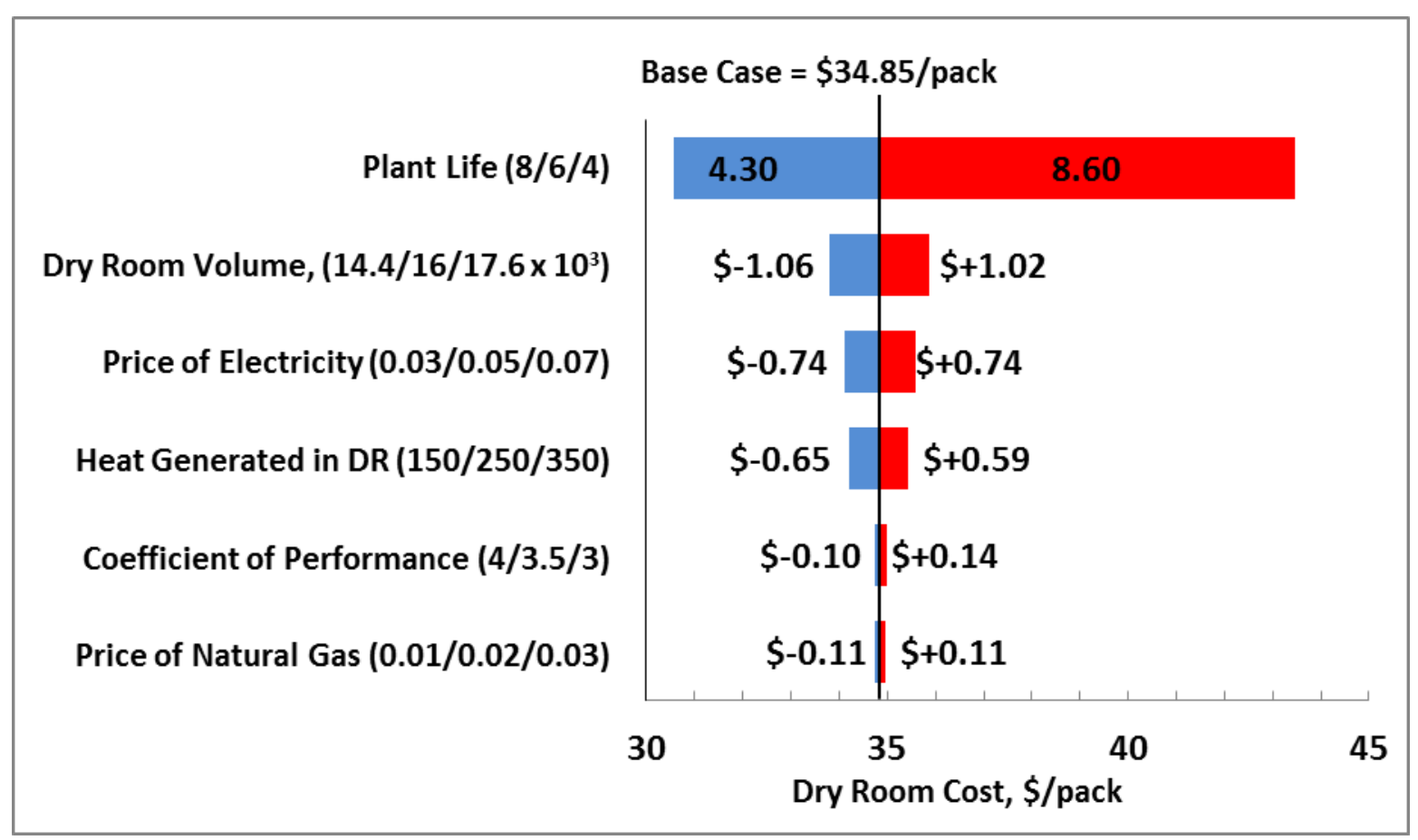

Figure 8. Effect of plant life (amortization period), dry room volume, price of electricity, heat generated in the dry room, the Coefficient of Performance, and the price of Natural Gas on the operating cost of the dry room in dollars per pack. The numbers in the plot represent the differential from the base case cost of $\$ 34.85$ per pack.

\subsection{A More Favorable Case}

After reviewing the effects of various design and operating conditions, a more favorable set can be selected such that it lowers both the energy consumption and cost of operations. The following explores some options:

- Lowering the purge rate will reduce both the cost and energy demand (Figure 7). The savings has to be balanced against the risk of potential for impurity buildup at low purge rates. 
- Sizing the heat exchanger in the desiccant regeneration loop showed a reduction in operating costs, where the differential savings diminish at the larger approach temperatures (Figure 2). However, a smaller heat exchanger will increase the total energy demand of the plant and therefore the greenhouse emissions footprint.

- Increasing the temperature setting at the Pre-Cool station indicates a savings in total energy demand and the cost. However, this also transfers the burden of moisture removal to the zeolite wheel, which is likely to increase the cost of maintenance and renewal, a feature that is not adequately captured in these calculations. Removing the moisture from the small volume of make-up air is perhaps more effective than removing it from the large volume of air going to the dry room.

- Improvements in the battery manufacturing process to reduce the moisture removal load should have a marked effect on the cost of the dry room operation.

The cumulative effects of the combination of eliminating the Pre-Cool station and the heat exchanger are shown in Table 11. The former reduces the energy demand by $12 \%$ (relative to the base case), and then the elimination of the heat exchanger increases the energy demand up to $487 \mathrm{~kW}$, or $22 \%$ above the base case. The cost of operations for the combination of changes is reduced to $\$ 32$ from the base case of $\$ 35$ per pack. 
Table 11. Cumulative effects of progressive changes in the design and operating conditions on energy demand and costs.

The scenarios simulated for this study are based on steady state conditions. Real systems are dynamic and are therefore typically sensor driven, where the air quality (humidity, temperature, concentrations of key components e.g., $\mathrm{CO}_{2}$, etc.) in the dry room and at various points within the system are monitored continuously. When the ambient air has low humidity or the moisture released/introduced into the dry room is lower than the rated capacity, the automated controller with an appropriate algorithm can reduce the energy demand and cost by a combination of one or more of the following: (i) lowering the purge / fresh feed rate, (ii) raising the temperature set points at Pre-Cool and Cool stations, (iii) slowing the revolution rate of the desiccant wheel. The combination of sensors and a smart controller enable the detection of or prediction of off-design conditions and are beneficial in that the system will not need to be designed for excessive large air flow rates to recover from upset conditions, such as frequent or prolonged opening of the air lock door, introduction of a batch of materials with higher moisture content, number of workers present in the room being more than designed, or some system level degradations such as flow controllers or component failures. The development of the algorithm for these controllers would be helped with a risk analysis that anticipates the probability of various upset conditions.

\section{Conclusions}


The results from the process model provide an understanding of the interactions of the design and operating parameters. Such a model (or its results) can be incorporated in the process control algorithm of a dry room so that the operation is optimized for a given ambient air condition.

Sensitivities of the various input parameters indicate that the amount of air needed has the biggest impact on the energy need and the cost of operations.

- The mass of air that flows through the dry room affects the energy needs and the size of the equipment, and directly affects the cost of operations. Thus, smaller rooms operating with low turnovers can reduce the energy demand and cost.

- The heat exchanger plays a very important role in recycling heat. The cases studied suggest that eliminating the heat exchanger would reduce the dollar cost. However, that would sharply increase the total energy demand of operating the dry room.

- Even though low purge rates reduce the cost of operations, certain minimum purging is necessary to avoid excessive concentration increases of byproduct gases generated within the dry room.

- Lowering the Pre-Cool temperature reduces the moisture removal load at the zeolite wheel, but increases the overall cooling load and the energy demand. 
Ultimately, the energy demand and cost of operations is dependent on the quantity of air that has to be managed, which is directly dependent on the volume of the dry room, the air turnover rate in the dry room, and the amount of purge necessary.

\section{Abbreviations}

$\begin{array}{ll}\text { COP } & \text { Coefficient of Performance } \\ \text { gpp } & \text { grains per lb } \\ \text { kW } & \text { kilowatt } \\ \text { LIB } & \text { Lithium ion batteries } \\ \text { NG } & \text { Natural gas } \\ \text { PHEV } & \text { Plug-in Hybrid Electric Vehicle } \\ \text { ppmv } & \text { Parts per million by volume } \\ \text { RH } & \text { Relative Humidity } \\ \text { scfm } & \text { Standard cubic foot per minute }\end{array}$

\section{Acknowledgments}

The authors wish to acknowledge Kevin G. Gallagher and Gary Henriksen for their help in preparing this manuscript. Support from David Howell and Peter Faguy at the Vehicle Technologies Office, Office of Energy Efficiency and Renewable Energy, U.S. Department of Energy, , is gratefully acknowledged. The submitted manuscript has been created by UChicago 
Argonne, LLC, Operator of Argonne National Laboratory ("Argonne"). Argonne, a U.S.

Department of Energy Office of Science laboratory, is operated under contract no. DE-AC02-

06CH11357. The U.S. Government retains for itself, and others acting on its behalf, a paid-up nonexclusive, irrevocable worldwide license in said article to reproduce, prepare derivative works, distribute copies to the public, and perform publicly and display publicly, by or on behalf of the Government. 


\section{Bibliography}

D. Chung, E. Elgqvist and S. Santhanagopalan, "Automotive Lithium-Ion Battery (LIB)

1] Supply Chain and U.S. Competitiveness Considerations," 2015.

J. Pinho, "Dry Rooms: Why they are needed and a Review of the complex issues

2] associated with building them - particularly the large ones required to mass produce lithium batteries," Advanced Battery Technology, vol. 46, no. 10, 2010.

Tesla Motors, [Online]. Available: http://www.teslamotors.com/gigafactory.

3]

C. Barlow, "Reaction of Water with Hexafluorophosphates and with Li

4] Bis(perfluoroethylsulfonyl)imide Salt," Electrochemical and Solid-State Letters, vol. 2, no. 8, pp. 362-364, 1999.

L. Yang, M. Furczon, A. Xiao, B. Lucht, Z. Zhang and D. Abraham, "Effect of impurities

5] and moisture on lithium bisoxalatoborate (LiBOB) electrolyte performance in lithium-ion cells," Journal of Power Sources, vol. 195, pp. 1698-1705, 2010.

M. Koltypin, D. Aurbach, L. Nazar and B. Ellis, "On the Stability of LiFePO4 Olivine

6] Cathodes under Various Conditions (Electrolyte Solutions, Temperatures)," Electrochemical and Solid-State Letters, vol. 10, no. 2, pp. A40-A44, 2007.

R. S. Smith, "Advanced Dry Room Concepts," in First Battery Technology Symposium on 
7] Advanced Secondary Batteries, Seoul, Korea, 1996.

K.-S. Lee and S.-H. Choi, "Effect of geometric parameters on ventilation performance in 8] a dry room," Drying Technology, vol. 20(7), pp. 1445-1461, 2002.

V. Manek, K. Mindjov, G. Staikov and A. Nassalevska, "Battery dry room facility.

9] Relationship between the dry room parameters and the moisture control unit.," Journal of Power Sources, vol. 26, pp. 603-605, 1989.

"Equivalency Results," U.S. EPA, [Online]. Available:

10] http://www.epa.gov/energy/greenhouse-gas-equivalencies-calculator. [Accessed 24 November 2015].

M. Peters, K. Timmerhaus and R. West, Plant Design and Economics for Chemical

11] Engineers, Third ed., McGraw-Hill HIgher Education, 2003.

P. Nelson, K. Gallagher and I. Bloom, "BatPaC (Battery Performance and Cost)

12] Software," Argonne National Laboratory, 2012. [Online]. Available: http://www.cse.anl.gov/BatPaC/.

P. Nelson, K. Gallagher, I. Bloom and D. Dees, "Modeling the Performance and Cost of 13] Lithium-Ion Batteries for Electric Vehicles," 2011.

Hengye USA, [Online]. Available:

14] http://www.hermescatalyst.com/images/stories/pdf/Hermes_application_brochure.pdf. 
Page $\mathbf{2 7}$ of $\mathbf{3 5}$ 
Table 1. Assumed / Input Parameters in Dry Room Process Model (Base Case)

\begin{tabular}{|c|c|}
\hline Assumption / Input Parameter & Value \\
\hline Ratio of Dry-Room-Air to Make-Up-Air & 19 \\
\hline Make-Up Air Temperature & $33^{\circ} \mathrm{C}$ \\
\hline Make-Up Air Relative Humidity & $50 \%$ \\
\hline Temperature after Pre-Cool (A2) & $9^{\circ} \mathrm{C}$ \\
\hline Temperature rise through Filter and Blower (A5) & $3^{\circ} \mathrm{C}$ \\
\hline Temperature after Cooler (A5-A6) & $10^{\circ} \mathrm{C}$ \\
\hline Moisture Level in Dry Room Inlet Air & 15 ppmv (0.066 gpp) \\
\hline Desiccant Capacity (MS-4A) & $0.15 \mathrm{~g}_{\mathrm{H} 2 \mathrm{O}} / \mathrm{g}_{\text {solid }}$ \\
\hline Desiccant in Solid Support & 1 wt. $\%$ \\
\hline Heat of Adsorption (MS-4A) & $4,200 \mathrm{~kJ} / \mathrm{kg}_{\mathrm{H} 2 \mathrm{O}}$ \\
\hline No. of Persons in Dry Room (30 workers x 24 hours) & 720 man-hours/day \\
\hline Moisture Contribution from Personnel & $1500 \mathrm{gr} / \mathrm{man}$-hour [7] [9] \\
\hline Moisture Content in Negative Electrodes & 0.05 wt. $\%$ \\
\hline Door Opening / Closing & 120 per day \\
\hline Moisture Level of Dry Room Exit Air & 100 ppmv (0.44 gpp) \\
\hline Heat Generated in Dry Room (Equipment+Personnel) & $250 \mathrm{~kW}$ \\
\hline Desiccant Regeneration Temperature & $146^{\circ} \mathrm{C}$ \\
\hline Heat Exchanger Approach Temperature & $20^{\circ} \mathrm{C}$ \\
\hline Heat Transfer Coefficient for Heat Exchanger & $\begin{array}{l}10 \mathrm{Btu} / \mathrm{h}-\mathrm{ft}^{2}-{ }^{\circ} \mathrm{F} \\
1.36 \mathrm{E}-3 \mathrm{cal} / \mathrm{s}-\mathrm{cm}^{2}-{ }^{\circ} \mathrm{C}\end{array}$ \\
\hline COP for Refrigeration System & 3.5 \\
\hline
\end{tabular}


Table 2. Moisture Content and Energy Demands in the Process (Base Case)

\begin{tabular}{|c|c|c|}
\hline Calculated Results & & \\
\hline Moisture Content at A2 & $\begin{array}{l}1.14 \% \\
\text { (50 gрp) }\end{array}$ & \\
\hline Moisture Removed at Pre-Cool (A1-A2) & $10.6 \mathrm{~g} / \mathrm{s}$ & \\
\hline Cooling Load at Pre-Cool (A1-A2) & & $57 \mathrm{~kW}$ \\
\hline Temperature of Blended Air Stream at A3 & $24^{\circ} \mathrm{C}$ & \\
\hline Moisture Content at A3 & $\begin{array}{l}659 \text { ppm } \\
2.9 \text { gpp }\end{array}$ & \\
\hline Moisture Removed at Cool (A5-A6) & - & \\
\hline Cooling Load at Cool (A5-A6) & & $426 \mathrm{~kW}$ \\
\hline Moisture Removed at Desiccant Wheel (A7-A8) & $9.5 \mathrm{~g} / \mathrm{s}$ & \\
\hline Cooling Load at Post Cool (A9-A10) & & - \\
\hline Heating Load at Post-Heat (A9-A10) & & $63 \mathrm{~kW}$ \\
\hline Dry Room Inlet Temperature (A10) & $14^{\circ} \mathrm{C}$ & \\
\hline Air Flow through Dry Room & $19.6 \mathrm{~m}^{3} / \mathrm{s}$ & \\
\hline Desiccant Regeneration Heat Load (B10-B11) & & $30 \mathrm{~kW}$ \\
\hline Total Cooling Load & & $483 \mathrm{~kW}$ \\
\hline Electric Power for Refrigeration & & $138 \mathrm{~kW}$ \\
\hline Electric Power for Blowers & & $167 \mathrm{~kW}$ \\
\hline Total Thermal + Electric Load & & $398 \mathrm{~kW}$ \\
\hline
\end{tabular}


Table 3. Costs for the Base Case System

\begin{tabular}{|l|r|}
\hline Cost of Delivered Capital Equipment & $\$ 741,000$ \\
\hline Cost of Electricity (\$0.05/kWh, \$367/day) & $\$ 134,000$ per year \\
\hline Cost of Natural Gas (\$0.02/kWh, \$44/day) & $\$ 16,000$ per year \\
\hline Cost of Labor (14 man-hours/day) & $\$ 78,000$ per year \\
\hline Cost of Utilities & $\$ 180,000$ per year \\
\hline
\end{tabular}


Table 4. Assumed Input Parameters in Cost Estimate

\begin{tabular}{|c|c|c|c|}
\hline Assumption / Input Parameter & Estimated \% & Of & Range \% \\
\hline \multicolumn{4}{|l|}{ 1. Direct Costs } \\
\hline A. Purchased Equipment & Model & & Model \\
\hline Installation & Model & Purchased Equipment & $25-55 \%$ \\
\hline B. Buildings, process and auxiliary & $30 \%$ & Purchased Equipment & $20-60$ \\
\hline C. Service facilities and yard improvements & $40 \%$ & Purchased Equipment & $40-60$ \\
\hline D. Land & $0 \%$ & Purchased Equipment & 0 \\
\hline \multicolumn{4}{|l|}{ 2. Indirect Costs } \\
\hline A. Engineering and supervision & $5 \%$ & Direct Costs & $5-10$ \\
\hline B. Construction expense and contractor's fee & $10 \%$ & Direct Costs & $5-15$ \\
\hline C. Contingency & $5 \%$ & Fixed Cap. Investment & $5-10$ \\
\hline \multicolumn{4}{|l|}{ 3. Fixed Capital Investment $=I+I I$} \\
\hline 4. Working Capital & $5 \%$ & Fixed Cap. Investment & $5-10$ \\
\hline \multicolumn{4}{|l|}{ 5. Total Capital Investment = III + IV } \\
\hline \multicolumn{4}{|l|}{ I. Operating Cost, $\$ /$ year } \\
\hline \multicolumn{4}{|l|}{ A. Direct Product Costs } \\
\hline Raw Materials & Model & & Model \\
\hline Operating labor & Model & & Model \\
\hline Direct supervisory and clerical labor & $15 \%$ & Operating Labor & $10-20$ \\
\hline Utilities & Model & & Model \\
\hline Maintenance and Repairs & $5 \%$ & Fixed Cap. Investment & $2-8$ \\
\hline Operating supplies & $0.5 \%$ & Fixed Cap. Investment & $0.5-1$ \\
\hline Laboratory charges & $10 \%$ & Operating Labor & $10-15$ \\
\hline Patents and royalties & $0 \%$ & Total Product Cost & 0 \\
\hline \multicolumn{4}{|l|}{ B. Fixed Charges } \\
\hline Depreciation & Model & & Model \\
\hline Local taxes & $3 \%$ & Fixed Cap. Investment & $1-4$ \\
\hline Insurance & $1 \%$ & Fixed Cap. Investment & $0.6-1$ \\
\hline Rent & $0 \%$ & Fixed Cap. Investment & 0 \\
\hline C. Plant Overhead Costs & $10 \%$ & Total Product Cost & $5-15$ \\
\hline \multicolumn{4}{|l|}{ II. General Expenses } \\
\hline A. Administrative costs & $2 \%$ & Total Product Cost & $2-6$ \\
\hline B. Distribution and selling costs & $0 \%$ & Total Product Cost & 0 \\
\hline C. $R \& D$ costs & $1 \%$ & Total Product Cost & $1-3$ \\
\hline D. Financing & $6 \%$ & Fixed Cap. Investment & $3-8$ \\
\hline III. Total Operating Cost, $\$ /$ year $=1+$ II & & & \\
\hline
\end{tabular}


Table 5. Moisture Source in Dry Room

\begin{tabular}{|l|r|r|}
\hline Moisture Source in Dry Room & g/s & \% \\
\hline Personnel & 0.81 & 66 \\
\hline Door & $1.3 \times 10^{-4}$ & \\
\hline Negative Electrodes & 0.42 & 34 \\
\hline Total & 1.23 & 100 \\
\hline
\end{tabular}

Table 6. Moisture Entering and Leaving the System

\begin{tabular}{|l|r|r|}
\hline Moisture Source in Dry Room & In & Out \\
\hline Entering with Make-Up Air, g/s & 19.4 & \\
\hline Entering with Personnel \& Materials in Dry Room, g/s & 1.2 & \\
\hline Removed at Pre-Cool, g/s & & 10.6 \\
\hline Leaving with Discharge Air (B14), g/s & & 10.0 \\
\hline Total, g/s & 20.6 & 20.6 \\
\hline
\end{tabular}


Table 7. Effect of the Pre-Cool Temperature on Heating and Cooling

\begin{tabular}{|l|r|r|r|r|r|}
\hline Pre-Cool Temperature & $\mathbf{3 3}^{\circ} \mathbf{C}$ & $\mathbf{2 5}^{\circ} \mathbf{C}$ & $\mathbf{1 5}^{\circ} \mathbf{C}$ & $\mathbf{9}^{\circ} \mathbf{C}$ & $\mathbf{1}^{\circ} \mathbf{C}$ \\
\hline Cooling Load at Pre-Cool, kW & 0 & 10 & 38 & 57 & 76 \\
\hline Cooling Load at Cool, kW & 457 & 447 & 434 & 426 & 416 \\
\hline Cooling Load at Post-Cool, kW & - & - & - & - & - \\
\hline Total Cooling Load, kW & 457 & 457 & 472 & 483 & 492 \\
\hline Heating at Post-Heat, kW & 20 & 20 & 45 & 63 & 78 \\
\hline Regen Heat Load, kW & 34 & 34 & 32 & 30 & 28 \\
\hline Total Thermal Energy Load, kW & 54 & 54 & 77 & 93 & 106 \\
\hline Total Energy Need, kW & 351 & 351 & 379 & 398 & 414 \\
\hline Cost, \$ per pack & 34.36 & 34.36 & 34.64 & 34.85 & 35.04 \\
\hline
\end{tabular}

Table 8. Mass balance for water at two Pre-Cool temperature settings.

\begin{tabular}{|l|c|c|}
\hline Pre-Cool Temperature & $9^{\circ} \mathbf{C}$ & $\mathbf{3 3 ^ { \circ } \mathbf { C }}$ \\
\hline $\mathrm{H}_{2} \mathrm{O}$ Entering with Make-Up Air, g/s & 19.4 & 19.4 \\
\hline $\mathrm{H}_{2} \mathrm{O}$ Entering with Personnel \& Materials in Dry Room, g/s & 1.2 & 1.2 \\
\hline $\mathrm{H}_{2} \mathrm{O}$ Removed at Pre-Cool, g/s (\%)* & $\begin{array}{c}\text { (10.6 } \\
(51.5 \%)\end{array}$ & $\begin{array}{c}0 \\
(0.0 \%)\end{array}$ \\
\hline $\mathrm{H}_{2} \mathrm{O}$ Removed at Zeolite Wheel, g/s (\%)* & 9.5 & 19.6 \\
& $(46.0 \%)$ & $(94.9 \%)$ \\
\hline $\mathrm{H}_{2} \mathrm{O}$ Removed with Purge Stream at B7, g/s (\%)* & 0.5 & 1.0 \\
\hline $\mathrm{H}_{2} \mathrm{O}$ Removed at Discharge, g/s & $(2.5 \%)$ & $(5.1 \%)$ \\
\hline$* \%$ of Total $\mathrm{H}_{2} \mathrm{O}$ entering the process & 20.6 & 20.6 \\
\hline
\end{tabular}


Table 10. The heating and cooling needs, and the cost of operating the dry room at different purge rates.

\begin{tabular}{|l|r|r|r|r|}
\hline Purge Rate, \% & $\mathbf{5}$ & $\mathbf{1 0}$ & $\mathbf{1 5}$ & $\mathbf{2 0}$ \\
\hline Pre-Cool, kW & 57 & 119 & 190 & 269 \\
\hline Cool, kW & 426 & 429 & 432 & 435 \\
\hline Post-Cool, kW & - & - & 6.3 & 40.5 \\
\hline Total Cooling, kW & 483 & 548 & 628 & 745 \\
\hline Post-Heat, kW & 63 & 28 & - & - \\
\hline Regen Heat, kW & 30 & 70 & 120 & 178 \\
\hline Total Heating, kW & 93 & 99 & 120 & 178 \\
\hline Total Energy Need, kW & 398 & 448 & 521 & 645 \\
\hline Cost per Pack, \$/pack & $\$ 34.85$ & $\$ 35.76$ & $\$ 36.85$ & $\$ 38.37$ \\
\hline
\end{tabular}

Table 11. Cumulative effects of progressive changes in the design and operating conditions on energy demand and costs.

\begin{tabular}{|l|r|r|}
\hline & $\begin{array}{r}\text { Total } \\
\text { Energy } \\
\text { Demand }\end{array}$ & $\begin{array}{r}\text { Cost per } \\
\text { Pack }\end{array}$ \\
\hline Base Case & $398 \mathrm{~kW}$ & $\$ 34.85$ \\
\hline 1. Eliminate Pre-Cool & $351 \mathrm{~kW}$ & $\$ 34.36$ \\
\hline 2. Eliminate Heat Exchanger from Regeneration Loop & $487 \mathrm{~kW}$ & $\$ 32.01$ \\
\hline
\end{tabular}


Table 12. Effect of Ambient Air Temperature Heating and Cooling Needs, and Costs ( $\mathrm{RH}=50 \%)$.

\begin{tabular}{|l|r|r|r|r|r|r|}
\hline Ambient T, ${ }^{\circ} \mathbf{C}$ & $\mathbf{4 0}$ & $\mathbf{3 3}$ & $\mathbf{2 0}$ & $\mathbf{1 0}$ & $\mathbf{0}$ & $\mathbf{- 1 7 . 8}$ \\
\hline Ambient T, ${ }^{\circ} \mathrm{F}$ & 104 & 91.4 & 68 & 50 & 32 & 0 \\
\hline Pre-Cool Load, kW & 89 & 57 & 14 & 1 & 0 & 0 \\
\hline Cool Load, kW & 426 & 426 & 426 & 426 & 415 & 393 \\
\hline Post-Cool Load, kW & - & - & - & - & - & - \\
\hline Post-Heat Load, kW & 63 & 63 & 63 & 79 & 89 & 96 \\
\hline Total Energy Need, kW & 407 & 398 & 385 & 396 & 401 & 400 \\
\hline Cost of Electricity, K\$ & 138 & 134 & 128 & 127 & 125 & 122 \\
\hline Cost of Natural Gas, K\$ & 16.2 & 16.2 & 16.2 & 18.8 & 20.2 & 21.3 \\
\hline Cost per Pack, \$/pack & 35.11 & 34.85 & 34.51 & 34.53 & 34.50 & 34.38 \\
\hline
\end{tabular}

